\title{
Envisioning the future of territories to tackle demographic and employment challenges in sub-Saharan Africa
}

Jean-Michel SOURISSEAU - Nathalie BOUGNOUX - Jean-François BÉLIĖRES Robin BOURGEOIS - Mamy SOUMARÉ - Patrick RASOLOFO

In sub-Saharan Africa, the magnitude of the demographic challenge implies anticipating targets to be reached within the time horizon of the next generation, in all sectors of activity. We propose an operational methodology that can be implemented by policymakers and actors in rural territories to envision the future and to prepare their development strategy. This territorial foresight methodology combines an analysis of past local dynamics, a 20-year population projection and a participatory foresight process. It enables collective thinking on sustainable paths and provides a framework for monitoring and steering public territorial action.
High population growth in rural areas, an unprecedented impact on development strategies and resource management

S ub-Saharan Africa is following an unusual development path. It faces specific, unprecedented challenges for 2030-2050. According to the 2015 United Nations projections, its population is set to double by 2050 to reach 2.2 billion people, half of whom will be under 25 years of age. This increase also concerns rural areas, where the population will grow from 620 million people to more than 1 billion over the same period. The demographic transition is thus pushed back beyond 2050, as is the demographic dividend - a boost in economic productivity associated with a slowdown in population growth and a reduction in the number of dependents.

Agriculture is another specific feature. The sector employs more than $60 \%$ of the working-age population, and agricultural holdings are mostly small, labour-intensive family farms. Consequently, structural and economic change in sub-Saharan Africa is not following the same path as the industrialised or emerging countries. In those countries, industrialisation has been facilitated by rapid growth in agricultural productivity and the massive transfer of agricultural workers to the so-called modern sectors. In subSaharan Africa, the secondary and tertiary sectors are still mostly informal and are struggling to create employment and wealth.

Faced with these challenges, centralised and sectoral public policies persist, in spite of recurrent criticism that these policies are disconnected from local realities, segmented and fragmented: they are clearly permanent and are being reproduced. The mixed results of decentralisation reflect this inflexibility. The public institutions created through decentralisation lack resources; they are struggling to find their place within the existing political and administrative organisations. The secondary cities, which are disadvantaged in terms of infrastructure and strategic capacities, are failing to play their role as development hubs and catalysts of structural change. Consequently, industrialisation is concentrated in the capital cities and a small number of urban agglomerations.

In Mali, the Office du Niger region is a good illustration of this trend. With 120000 hectares of irrigated cropland and $40 \%$ of national rice production, the Office du Niger is a strategic region. But the lack of local infrastructure and 
energy is an obstacle to the creation of a food processing industry. Industries are thus based in Bamako, more than $250 \mathrm{~km}$ away, and the Office du Niger region has yet to see any real economic development leading to job creation.

With all of these constraints, it is difficult to see how the path of the industrialised or emerging countries can be replicated. The situation in sub-Saharan Africa therefore calls for a review of public policies and a shift towards alternative paths, with special attention to job creation, in which agriculture will play a different but decisive role.

Putting employment at the heart of new development strategies requires intersectoral approaches that focus on agricultural labour and pluriactivity. This implies encouraging agricultural production models and associated food systems that will foster local employment along the value chains, especially through product processing and the agri-food industry. At the same time, all sources of employment in the tertiary sector need to be harnessed. Finally, it is important that these development choices cover the diversity of contexts and produce solutions that are suited to each situation, both national and local.

To accompany the production of innovative policies, we propose an operational approach to territorial foresight, which encourages local actors to take ownership of their future and to rethink their present. This approach was designed and tested in two administrative regions, one in Mali and the other in Madagascar (box opposite).

\section{Participatory territorial foresight: taking ownership of the future to rethink local dynamics}

The participatory territorial foresight presented here is an operational approach to accompany local actors at the level of an administrative region, the first level of governance under the national level. It requires 6 to 18 months of work depending on the size of the region, the accessibility of data and the existing knowledge. It combines four interdependent phases, conducted by a team of development technicians and social scientists with the support of local civil society and the devolved and decentralised territorial administration.

A retrospective analysis. This analysis identifies and processes the data available for the region produced by the most recent major national surveys. It also uses regional development schemes, sectoral studies, academic reports, and outputs from research and expertise activities.

Two surveys. The surveys complement the analysis and highlight the respondents' representations of the future. They involve at least 30 resource persons selected at the end of the analysis phase, as well as a representative sample of local diversity including at least 200 households chosen by experts based on the results of the major statistical surveys available.

\section{Participatory territorial foresight applied to two regions in Mali and Madagascar}

This methodology has been tested in the Ségou region in Mali [62 $500 \mathrm{~km}^{2}, 2.8$ million inhabitants in 2015] and in the Vakinankaratra region in central Madagascar [19 $000 \mathrm{~km}^{2}, 2$ million inhabitants in 2015]. Below is a summary of the four phases conducted in 2015.

Analysis: rural urbanisation, mobility, the weight of the informal sector and of agriculture. In both regions, villages are mushrooming and becoming increasingly populated, while the cities are struggling to emerge as economic hubs capable of absorbing a significant number of newcomers to the job market and enabling them to leave agriculture. Mobility, which is seasonal and short distance, is essential to securing a livelihood. The economy is based on the informal sector $[97 \%$ of jobs identified] and on pluriactivity. But it is dominated by family farming, and to a much lesser extent by small urban trades.

Household surveys: security and governance are lacking. The need for security of goods and people was underlined, along with the lack of public goods and the difficulties implementing decentralisation. Large families, with at least four children per woman, are seen as the best safeguard against uncertainty. Attention is focused on agriculture. The agri-food industry is the main prospect for industrialisation and growth, far more than handicrafts, which remain in the informal sector.

Projections: the population boom is underway at the regional level. From 2015 to 2035, the population of the Ségou region will grow from 2.5 to 4.2 million people, and that of the Vakinankaratra region from 2 to 3.1 million people. By 2035, a million new jobs need to be created in Ségou and 700000 in Vakinankaratra, in other words a rate of job creation double that of the 2000 s. Educational and health requirements are immense, yet the resources allocated to them are increasing very little. Regional planning issues are crucial, as there is already a great deal of tension between agricultural land and natural resources.

Participatory workshops: taking ownership of the future to rethink the present. For the participants, the territory is multi-dimensional, and security, access to energy and governance are essential. Eight driving forces for the future are identified in order to subsequently design future scenarios:

> in Ségou: security, energy, mining potential, communications infrastructure, the informal sector, the direction of local economic development, territorial governance, and public financing;

> in Vakinankaratra: security, energy, demographic pressure, capacity for economic organisation, financing for local development, structural inequalities, marketing, and poverty.

The participants stressed that without proactive, farreaching policies at the local and national levels, local resources, which are perceived as being abundant, will not be activated. 
Population projections for $\mathbf{2 0 3 5}$ and $\mathbf{2 0 5 0}$. These projections characterise the regional demographic challenge and its impact on requirements in terms of employment, agricultural land, education and health. These regional dynamics are compared with national changes in order to understand the interrelationships between the spatial and administrative levels. The projections are based on the age structure of the population and on fertility and mortality assumptions generated using data from the latest local census and from the United Nations.

\section{One or several participatory workshops lasting a week or}

more. Their goal is to identify the driving forces affecting the future of the territory and to develop alternative scenarios. They involve around 30 actors recognised for their knowledge of the territory or their capacity to share the perspectives of significant social groups. These participants are also chosen so as to cover the diversity of key issues in the region. The development technicians and researchers facilitate the workshop using the analysis and projections produced. The participants identify the driving forces in the territory, in other words those with the greatest influence on the future. To do so, the facilitators encourage participants to discuss the influence of around 50 variables taken in pairs and resulting from the analysis. They are asked to be mindful of the processes already underway and the latent processes that could become drivers in the future. Next, exploratory scenarios are developed by combining the different plausible states of the driving forces. Through this scenario building process, participants move from individual representations to a collective ownership of future challenges.

This type of anticipatory process and collective ownership of possible futures enables local decision-makers to reinterpret the present and to propose changes to existing policies. The teamwork during workshops and resulting exchanges beyond this circle produce shared, multisectoral knowledge of the territory. The factors of change and the policy space are also better understood.

\section{Putting the territory and its actors at the heart of public policy}

This territorial foresight approach is innovative in that it forms a basis for transforming the development policies within a territory. Further work would entail starting again from scenarios and driving forces to enable competent actors to work together to develop actions to achieve desirable futures. But even without this next phase, by participating in analyses and scenarios, local actors gain greater awareness of the scale of challenges in their territory and of their capacity to address them. These challenges are usually seen as pertaining to the national and global levels at which local actors are not called upon to act.

The two territorial foresight activities conducted in Mali and Madagascar identify agriculture as a major key to the future. They show that agricultural models that generate employment and drive multi-sectoral development can only be built under certain conditions. In particular, these new models need to maximise a package of environmental and social services in addition to the volume of agricultural production. Labour-intensive family farming based on agroecology could increase the ecological, economic and social performances of agricultural and food systems. This option is worth exploring, taking account of local situations and their different prospects in terms of employment and economic diversification. Their performances should also be assessed in relation to other options, such as the agribusiness and "green revolution" productivity-based models advocated by agricultural policies in many sub-Saharan African countries.

The two foresight studies also pinpoint four key actions to address current challenges in rural African territories:

$>$ identifying and building capacities, knowledge and good practices in regional administration and more generally in decentralised public services;

> strengthening linkages between agriculture and upstream and downstream activities;

> strengthening linkages between the capital, secondary cities and rural territories;

$>$ rebalancing services and infrastructures between villages, secondary cities and the capital to enable the diversification of activities and employment.

In order to implement and leverage these actions, decentralisation policies need to be consolidated and adapted, especially those that share strategic decisionmaking between the national and local levels. Indeed, decentralisation can only be effective if local competences exist, but it requires a consistent national framework. It is therefore the responsibility of governments to ensure the local exercise of competences that were formerly those of the central State. Activating decentralisation gives local policymakers the possibility to anticipate and plan territorial development.

This territorial foresight methodology provides local policymakers with an instrument that explores the challenges at the time horizon of the next generation. While they cannot predict the future, they can use scenarios to understand current trajectories, explore uncertainties and design innovative and sustainable territorial public policies. This methodology can facilitate the transition from territorial projections to the definition of a viable, shared territorial project. Varying the state of a driver that influences the future makes it possible to anticipate the way this change will impact the local trajectory, provided external influences, lessons from the territorial analysis and capital and infrastructure requirements are also taken into account. Likewise, the future scenarios developed in this way can be used to assess the longer term impact of public policies implemented today. 
Perspective $\mathrm{n}^{\circ} 44$ is based on the research project Prospective territoriale sur les dynamiques démographiques et le développement rural en Afrique subsaharienne et à Madagascar (Territorial foresight on population dynamics and rural development in sub-Saharan Africa and Madagascar], financed by the French Development Agency [AFD, www.afd.fr/en] and conducted in 2015-2016 by CIRAD in association with the Institut d'Economie Rurale (IER, Rural Economy Institute] in Mali and the Institut International de Sciences Sociales (IISS, International Institute for Social Sciences, https://iissmada.wordpress.com/] in Madagascar.

This research is published in the following book:

Sourisseau J.-M., Bélières J.-F., Bourgeois R., Soumaré M., Rasolofo P., Guengant J.-P., Bougnoux N., 2017. Penser ensemble l'avenir d'un territoire. Diagnostic et prospective territoriale au Mali et à Madagascar. Paris, AFD. Études de I'AFD n¹5, 179 p. ISSN 2492-8313. https://www.afd.fr/fr/penser-ensemble-avenir-territoire.

This research has also given rise to the following publications:

Bourgeois R., Sourisseau J.-M., Rasolofo P., Bougnoux N., Ramanitriniony Haja K., Rabeandriamaro H., Bélières J.-F., 2016. Atelier de prospective participative
Les avenirs de Vakinankaratra en 2035. Paris, AFD, 38 p. http://agritrop.cirad.fr/580520/.

Bourgeois R., Sourisseau J.-M., Soumaré M., Coulibaly B., Bélières J.-F., Bougnoux N., 2016. Atelier de prospective participative Les avenirs de Ségou en 2035. Paris, AFD, 35 p. http://agritrop.cirad.fr/580519/.

Sourisseau J.-M., Bougnoux N., Bélières J.-F., Bourgeois R., 2017. Territory-centred thinking and action for a better future: territorial foresight in the regions of Ségou in Mali and Vakinankaratra in Madagascar. In Living territories to transform the world. Caron P., Valette E., Wassenaar T., Coppens D'Eeckenbrugge G., Papazian V. [Eds]. Versailles, Editions Quae, p. 243-253. ISBN 978-2-7592-2731-0.

Sourisseau J.-M., Rasolofo P., Bélières J.-F., Guengant J.-P., Ramanitriniony Haja K., Bourgeois R., Razafimiarantsoa Tovonirina T., Andrianantoandro Voahirana T., Ramarijaona M., Burnod P., Rabeandriamaro H., Bougnoux N., 2016. Diagnostic territorial de la région du Vakinankaratra à Madagascar. Paris, AFD, 157 p. http://agritrop.cirad.fr/580518/.

Sourisseau J.-M., Soumaré M., Bélières J.-F., Guengant J.-P., Bourgeois R., Coulibaly B., Traoré S., 2016. Diagnostic territorial de la région de Ségou au Mali. Paris, AFD, 150 p. http://agritrop.cirad.fr/580517/.

\section{A few words about...}

Jean-Michel Sourisseau is a socio-economist in UMR ART-Dev at CIRAD (Joint Research Unit, Actors, Resources and Territories in Development, http://art-dev.cnrs.fr/]. He is the CIRAD focal point for family farming. jean-michel.sourisseau@cirad.fr

Nathalie Bougnoux is a project team leader in the Agriculture, rural development and biodiversity division at AFD (French Development Agency, www.afd.fr/en). She has worked for many years on population and migration dynamics and has launched a number of foresight studies at AFD

\section{bougnouxn@afd.fr}

Jean-François Bélières is an agroeconomist in UMR ART-Dev at CIRAD, and is currently based in Madagascar at FOFIFA (National Centre for Applied Research and Rural Development, www.fofifa.mg) in CIRAD's platform in partnership for research and training, SPAD (Highland production systems and sustainability in Madagascar, www.dp-spad.org/]. He focuses on the impacts of rural development policies on farms and local economies

jean-francois.belieres@cirad.fr

Robin Bourgeois is a foresight analyst in UMR ART-Dev at CIRAD. He is currently based in South Africa, conducting applied research on foresight, governance and territorial development.

robin.bourgeois@cirad.fr

Mamy Soumaré is a geographer and researcher at the Institut d'Economie Rurale (IER - Rural Economy Institute, Mali), as well as a professor at the University of Bamako. His research focuses on the representation and modelling of spatial dynamics.

soumare_mamy@hotmail.com

Patrick Rasolofo is a rural development economist. He is the founder and Director of the Institut International des Sciences Sociales (IISS, International Institute for Social Sciences, Madagascar, https://iissmada.wordpress.com//.

iiss@moov.mg

\begin{tabular}{ll}
\hline CC. This article is provided & To cite this document \\
under the terms of the & Sourisseau J.-M., Bougnoux N., Bélières J.-F., \\
Creative Commons License & Bourgeois R., Soumare M., Rasolofo P., 2017. \\
BY NC SA & Envisioning the future of territories to tackle \\
CC-BYNC-SA 4.0: Attribution-NonCommercial- & demographic and employment challenges \\
Share-Alike 4.0 International (https:// & $\begin{array}{l}\text { in sub-Saharan Africa. CIRAD, Montpellier, } \\
\text { creativecommons.org/licenses/by-nc-sa/4.0/ } \\
\text { deed.en). }\end{array}$ \\
& $\begin{array}{l}\text { Perspective 44. } \\
\text { https://doi.org/10.19182/agritrop/00004 }\end{array}$
\end{tabular}

\section{Some links}

FAO, 2017. The State of Food and Agriculture. Leveraging Food Systems for Inclusive Rural Transformations. FAO, Rome. ISBN 97892-5-109873-8. www.fao.org/state-of-food-agriculture/en/.

Losch B., 2016. Structural transformation to boost youth labour demand in sub-Saharan Africa: The role of agriculture, rural areas and territorial development. Geneva, International Labour Office (ILO), Employment working paper $n^{\circ} 204$. www.ilo.org/employment/ Whatwedo/Publications/working-papers/WCMS_533993/lang--en/ index.htm

Pesche D., Losch B. and Imbernon J. [eds.), 2016. A New Emerging Rural World - An Overview of Rural Change in Africa. Second, revised and supplemented edition, NEPAD and CIRAD, 76 p. ISBN 978-2-87614-719-5. http://www.cirad.fr/en/publications-resources/ publishing/studies-and-documents/atlas-a-new-emerging-ruralworld-in-africa-2nd-edition.

United Nations, Department of Economic and Social Affairs, Population Division, 2017. World Population Prospects: The 2017 Revision, Key Findings and Advance Tables. Working Paper ESA/P/WP/248. https://esa.un.org/unpd/wpp/.

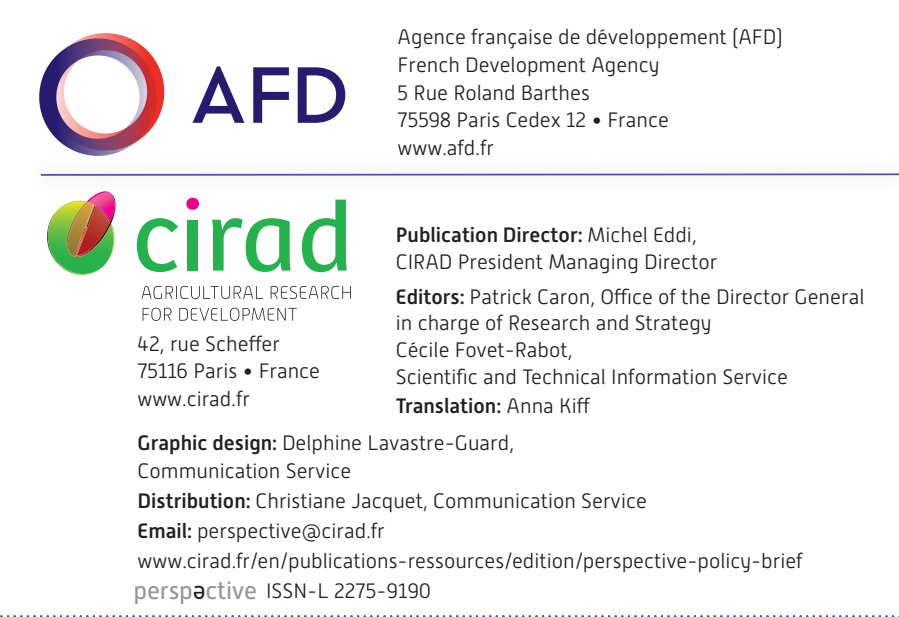

